\title{
Stand Structure Alterations in Forest Stands
}

\author{
Ana Cristina Gonçalves* \\ Department of Rural Engineering, University of Évora, Portugal
}

Submission: February 15, 2018; Published: May 02, 2018

"Corresponding author: Ana Cristina Gonçalves, Department of Rural Engineering, School of Science and Technology, Institute of Agrarian and Mediterranean Environmental Sciences (ICAAM), Institute of Advanced Research and Training, University of Évora, Portugal, Tel: +351266760800; Fax: +351266760911; Email: acag@uevora.pt

\begin{abstract}
Forest stands are usually classified according to regime (high forest or coppice), structure (even-aged or uneven-aged) and composition (pure or mixed). Through time there were shifts between the preferred stand structure frequently due to the desired productions; coppices for small dimension timber and high forest for large dimension ones, pure even-aged for a more uniform timber dimensions and quality and mixed or uneven-aged for when both timber and services were the target production. The alteration of regime (conversion of regime), structure (conversion of structure) and composition (transformation) has a long history in forestry. Overall, all regimes, structures and compositions contribute to the sustainability and diversity of the forest and their products and services. The alteration of stand structure varies from simple to very complex and from short to long term. The focus should be directed to a suite of guidelines, flexible models of silviculture and monitoring to enable adapting the silvicultural practices, especially during the transition phase from one stand structure to another.
\end{abstract}

Keywords: Conversion of regime; Conversion of structure; Transformation; Transition phase; Models of silviculture

\section{Introduction}

The vast forest areas have provided several products and services [1,2] and their management varies from overexploitation to of abandonment $[3,4]$. The development of silviculture occurred simultaneously with the shortage of forest products and was focused on providing wood and guided to the even-aged systems [1,5-9]; coppice systems for small dimension wood [7] and high forest for large dimension wood [5-9]. Meanwhile the reduction of the pressure on woody products and the environmental concerns altered the focus to broader production objectives that included timber, non-timber products and services. The paradigm's shift directed silviculture to new approaches where the emphasis was focused in multiple use systems and uneven-aged and mixed stands and the emulation of natural processes. This resulted in the development of many approaches, methods and techniques were developed [1,10-22] .

The variation of products and services expected from the forests created the need to develop methods, techniques and tools to enable the stand structure alteration. In the next sections it will be described and discussed the criteria and definitions used to classify (section 2) and to alter (section 3) stand structure, as well as the main forces that drove the shifts between the different stand structures.

\section{Stand Structure}

Forest stands are a group of trees linked by a set of patterns and interactions that originate the stand structure, which was determined by the past processes and where the ongoing processes determine the future one. Stand structure and their analysis is described in nearly all silvicultural text books [59,23-24] . It is used not only to describe the forest stands but also for their management, whether the stands' production is timber, non-timber products or services [9,23,25-28]. According to several authors [23-24,29] the variability of stand structure is wide and as it is determined by the tree's neighbours and their interactions. It is primordial to the stand development and dynamics, namely growth, mortality, silvicultural practices, harvests and regeneration. The variability of stand structure is also associated to some degree heterogeneity, both within and between stands, linked with the range of tree dimensions, their spatial arrangements in the horizontal and vertical planes and the number of species $[23,30]$. Stand structure can be defined as the spatial and temporal arrangement of the trees in a stand and is classified with three criteria; regime, structure and composition [5-9,23-24].

Regime of a stand is characterised by the type of regeneration: high forest for the stands where regeneration is of seed origin and coppice for those of vegetative origin $[5,7,24]$. However, there is a continuum from high forest to coppice (Figure 1) i. e, in the same stand can exist individuals of both seed and vegetative origin, thus originating intermediate forms, from the coppice with standards to the high forest with coppices. The threshold is set for the proportion of the number of individuals of each of the two types of regeneration [7]. Regime is also dependent on the species, while high forest is suited for all forest species, coppice can only be used with species that are able to sprout from stumps or roots [7,31] (Figure 1 ). 


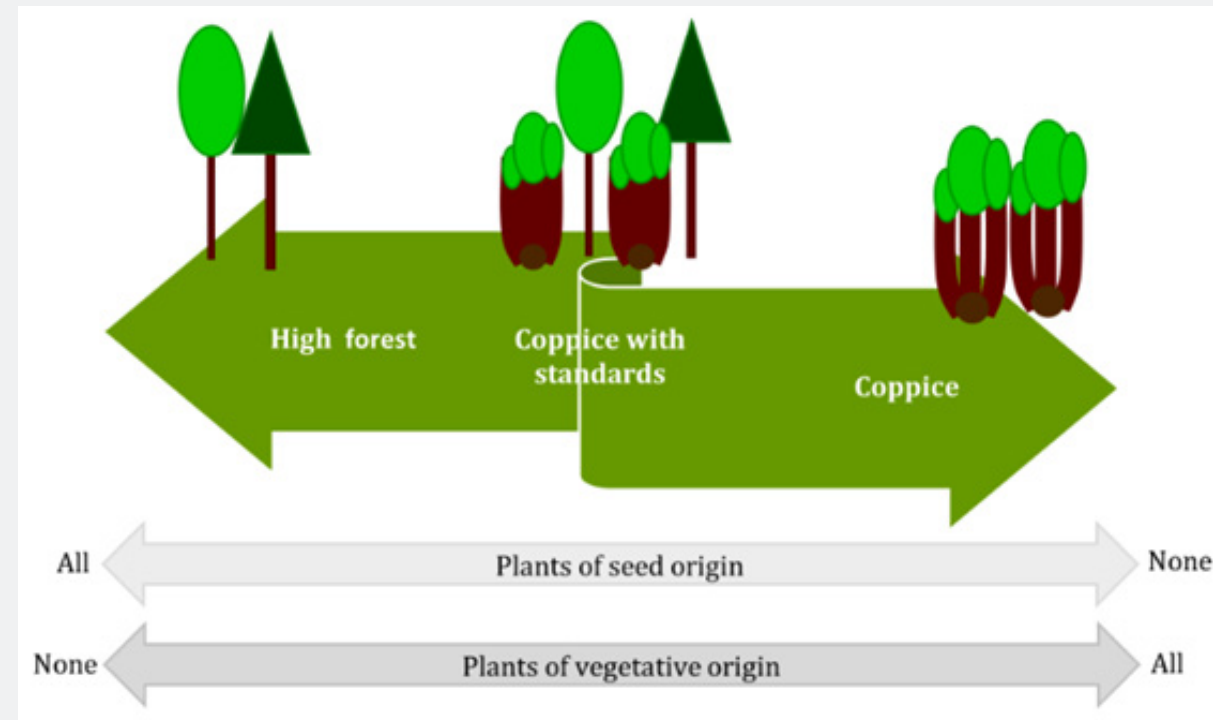

Figure 1: Representation of regime variability.

Coppice stands and forests have been a traditional management system in Europe [8,32,33]. The coppice system abandonment started in the late 19th century and was especially noticeable during the 20th century [33-36]. Inversely, from the late 20th century onwards there was a renewed interest on the coppice systems, especially with the increase importance of small dimension wood for biomass and energy [37,38] and their conservation values [38-40]. The success of coppices, when compared with the high forest, can be explained by the advantages that it brings to the producers, namely, simple management, easy and quick regeneration, fast growth, higher biomass production and $\mathrm{C}$ sequestration and thus short rotations resulting in a more frequent income [36,38,41-44]. Nonetheless same negative impacts are pointed out by some authors [45-49], such as soil erosion when clear cuts are used in large areas with steep slopes, removal of the soil organic horizon by the machinery, cuts of regular areas in large areas may have a strong impact on the landscape and high exports of nutrients. The coppices are frequently referred as having less diversity due to the spatial arrangement of the trees, as the stands are single layered, and due to the clear cuts at short time cycles [41]. However, their diversity is distinctive and seems to be related to the coppice management system, short rotations (5-30 years), i.e., and high spatial heterogeneity, host a wide range of species that are not present in high forest systems, and have higher resilience to water stress $[38,50]$.

Structure is characterised by the number of age classes or cohorts in the stand, varying from even-aged, one cohort to uneven-aged or multiaged, two or more cohorts [22,23,29] . At the even-aged extreme are the clonal plantations while at the uneven-aged are the Plenterwald (Figure 2), in between a continuum can be described, at least theoretically, as function of the number of cohorts and their proportion in the stand (Figure 2).

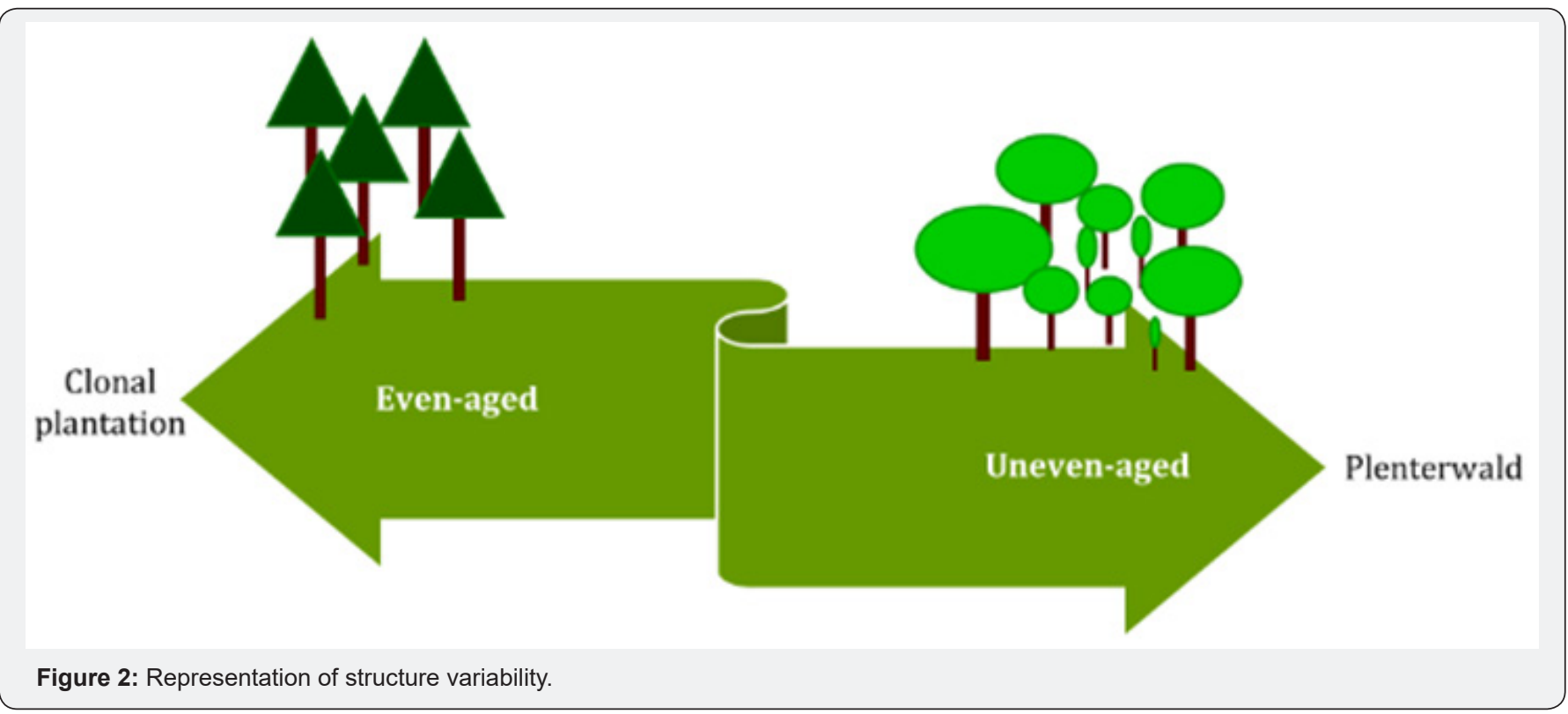


Uneven-aged stands are considered to have higher diversity than the even-aged ones, due to the wider range of tree ages and dimensions, spatial distribution in the horizontal and vertical planes, and are also considered to be able to have higher value for soil and water conservation and habitat diversity [51-53]. Conversely, even-aged stands are driven towards the efficiency of silvicultural operations, harvest, products uniformity and predictability [5-9,23-24,51]. Though uneven-aged silviculture dates back to the late 18th century, it gained renewed interest with the increasing awareness for diversity and sustainability $[22,29]$. The uneven-aged systems are characterised by the number of cohorts, target equilibrium of the number of individuals per cohort and regeneration, preferentially natural, and recruitment able to maintain it [12-13,22,29]. According to [29] there should be made a distinction between the canopy heterogeneity and the silvigenic functionality. Some even-aged stands may have a heterogeneous canopy but they are not unevenaged. The latter encompass two or more cohorts; periodical or continuous recruitment, function of the number of cohorts; and an equilibrium for the proportion of the number of individuals per cohort, frequently determined by the Liocourt coefficient $[22,29]$. The primordial constraint to their management is their wide range of variability [51].

Composition refers to the number of species present in forest stands, either pure or mixed $[6,8,24]$ Theoretically, it can be said that it goes from 1 to $\mathrm{n}$ species, with all the individuals belonging to the same species or with each individual belonging to a different species (Figure 3). Nonetheless, usually the managed multispecies stands have 2 to 10 species, though larger number of species can be found in some natural forests [54-57]. Composition is generally evaluated with an absolute density measure (number of trees, basal area, volume or crown cover), and the major challenge is selecting the better suited measure and the threshold to distinguish between pure and mixed stands, being also of interest the form, type and degree of the mixture $[9,58,59]$ (Figure 3).

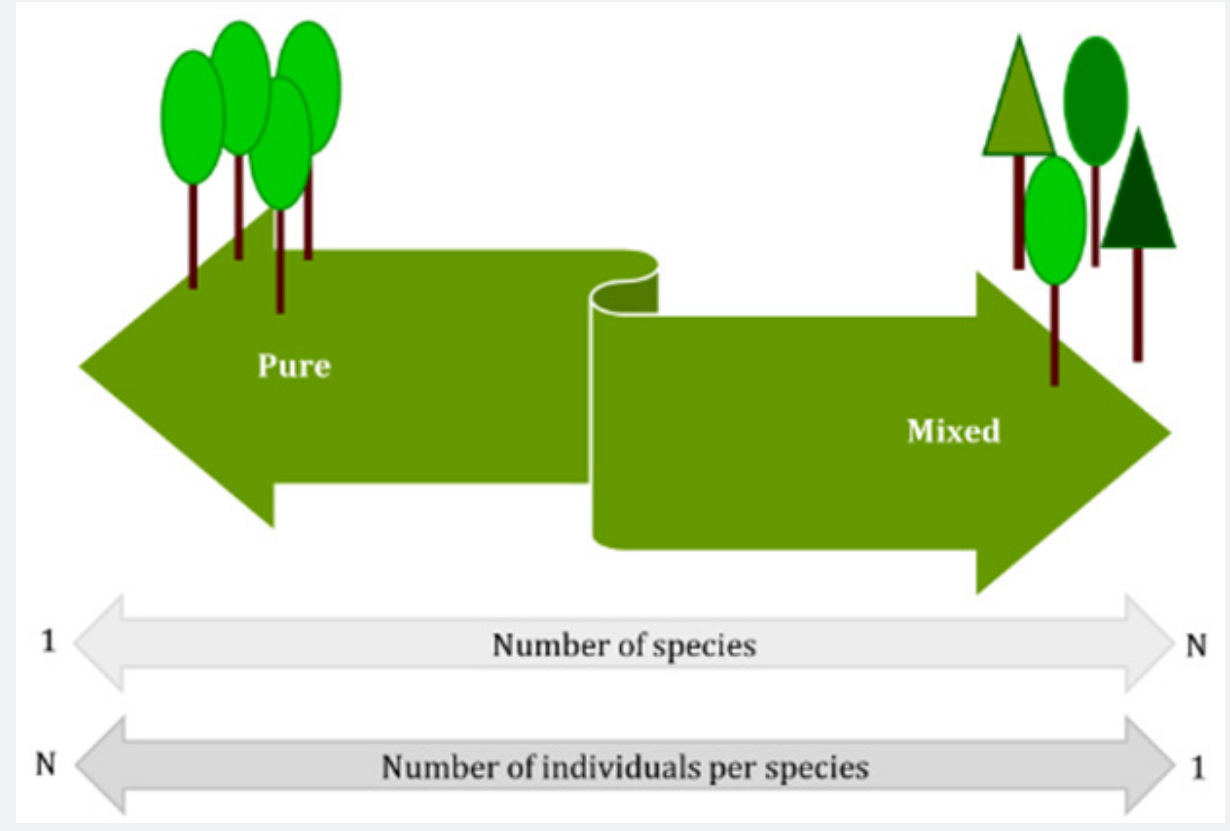

Figure 3: Representation of composition variability.

Mixed stands have a wide variability, function of the number of tree species, their proportion and spatial arrangement [5$9,24,56,60]$. When compared with the pure stands, have a wider range of productions; have higher resilience to disturbances; positive interactions are usually found in the stands, in particular when the complementary and sociability principles are met; have higher biodiversity; and encompass more risk dispersion [23-24,29,56-57,61-71]. The productivity of mixed stands seems to be linked to the number of species and their proportions [7274] with some authors referring that they are more productive [5,70,75-77] and others stating the opposite [78-81].

Stand structure originates a suite of horizontal and vertical distributions of the trees in a stand, which are frequently analysed by their description of the stand structure using absolute density measures, $[5,6,7,8,9,24]$ structure indices [7,9,22-24,82-87] and diversity indices [30,62-68,88-98]. In general, it can be said that a particular stand structure is better suited to a certain production. For example, pure even-aged coppices are preferred when small dimension wood is the target production while mixed uneven-aged stands are desired when timber and services are the target (Figure 4). This need adds new challenges to forest management and silviculture which encompass a set of methods and tools that enable the alteration of regime, structure and composition, resulting in transitions periods and flexible models of silviculture to promote and accomplish the alterations (Figure 4). 


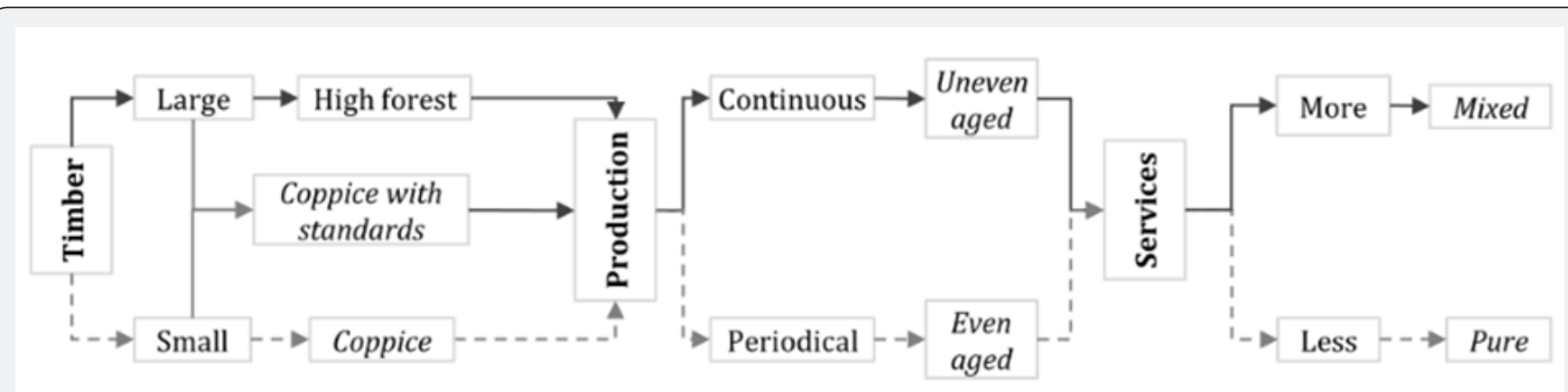

Figure 4: Relation between stand structure, productions and services.

\section{Alterations of Stand Structure}

The alterations of stand structure can be grouped in the following classes: conversion of regime, the alteration from a coppice to a high forest regime or the inverse, being also considered intermediate forms with individuals of both coppice and high forest; conversion of structure, the alteration from an even-aged to uneven-aged, that is from one cohort to two or more cohorts or the inverse; transformation, the alteration of composition from pure to mixed, that is from one species to two or more, or the inverse.

The alteration of stand structure is a process focused on cutting operations and regeneration, where stands are managed towards the target stand structure, regardless whether regeneration is natural or artificial. Also, spatial distribution, both horizontal and vertical, should be taken into consideration due to its implications in the future management. While the conversion of regime or structure considers the spatial arrangement per regeneration type or cohorts the transformations have also to consider the type, form and degree of mixture between species. Alteration can be an abrupt or gradual phenomenon, if it occurs during short or long time periods, respectively. The duration of the transition period from one stand structure to another depends on the species, their growth rate, type of regeneration and their development patterns and site quality. In this phase production fluctuations are expected and when preparing the alteration there should be considered its advantages and disadvantages, including at risk analysis $[22,29]$.

\section{Conversation of regime}

The conversion of regime (Figure 5) to high forest occurred principally when small dimension wood demand diminished and biodiversity and sustainability issues arose Mariotti et al. [41,99] while the conversion from high forest to coppice was driven by the increase of demand of small dimension wood, especially for biomass and energy, as well as when some specific conservation issues become of importance [37,38,39,40] (Figure 5).

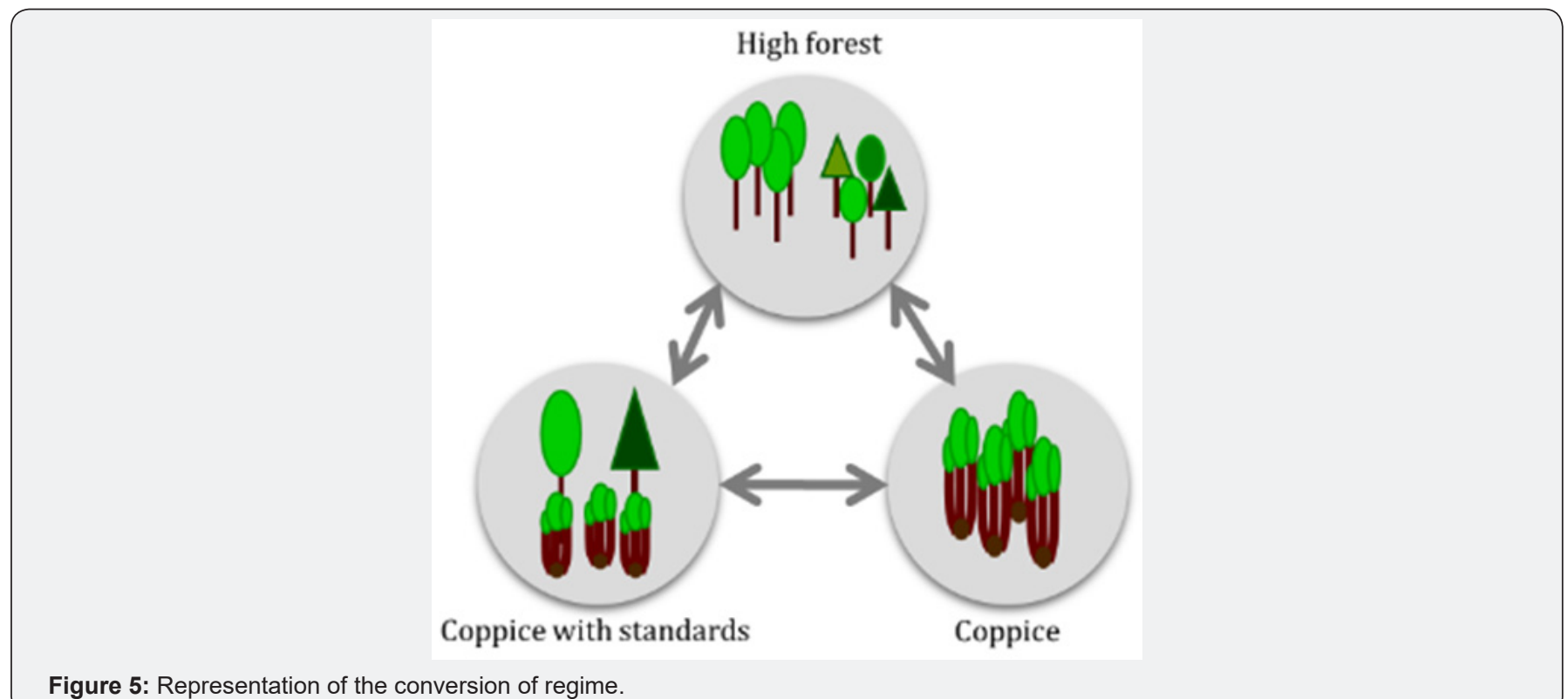

Figure 5: Representation of the conversion of regime.

The conversion of regime from high forest to coppice can be carried out by a single cut, clearcutting; or a set of cuts, whether a variant of clearcutting system or with the shelter wood systems. [34] Consider three methods: i. Clearcutting, dividing the management unit in compartments, where each one corresponds to an even-aged structure, but where at the management unit several age classes are represented. 
ii. The management unit is divided in compartments; some are maintained as high forest while others are clear cut using a regular pattern.

iii. Similar to the former but the areas of coppice have irregular and scatter spatial distribution.

The key elements of the conversion of regime from coppice to high forest are the cutting operations and the regeneration. The latter can be natural if seed production is foreseen abundant and frequent and is of good quality for the desired species. Contrariwise, artificial regeneration is used when seed source is scarce in quantity and/or quality, is infrequent or if it does not exist for the desired species $[7,8]$. It is a more or less complex process, which can be accomplished by a set of specific cultural practices [7], but due to the variability of the stands, species and sites should be flexible to enable adapting management [41].

The conversion of coppices in high forest stands with artificial regeneration can be group in four types [7]:

i. Clear cutting followed by plantation, with noncommercial thinning if necessary, and is indicated for robust and shade intolerant species with fast juvenile growth.

ii. Cut with reserve of sprouts, followed by plantation and the upper layer composed by the sprouts is removed in 1-3 cuts according to the need of direct sun light and protection of the planted species, being recommended for shade intolerant species that require slight temporary protection.

iii. Cut of protection in the coppice where rotation is enlarged by 25-30 years or more, followed by a cut of protection more or less heavy, depending on the species and site, by plantation, secondary cuts and final cut, removing gradually the coppice according to the need in light and protection of the plantation.

iv. Clear cutting with lateral protection, correspond to clear cuts in narrow bands followed by plantation.

The conversion of the with natural regeneration Mariotti et al. [41] can be done with:

i. Thinning from below, selecting at least three dominant sprouts per stump; and

ii. Selective thinning, selecting the best 1 or 2 sprouts per stump and releasing their crowns. The constraints associated with this type of conversion seem to be related to fruiting and root sprouting [36,100,101].

\section{Conversation of structure}

In the conversion of structure, the cutting operations (thinnings and cuttings) and the regeneration are distributed in time in order to promote the development of one or several cohorts (Figure 6). Special care should be given to the number of cohorts, their spatial distribution, both horizontal and vertical, and competition among individuals. The goal is to attain a stand in equilibrium for the desired number of cohorts. It results in a drastic change of structure $[22,29,51]$. It should also be bared in mind that the benefits attained with uneven-aged stands with two or three cohorts are similar to those of more cohorts, and which have an easier and more cost-efficient management [29] (Figure 6).

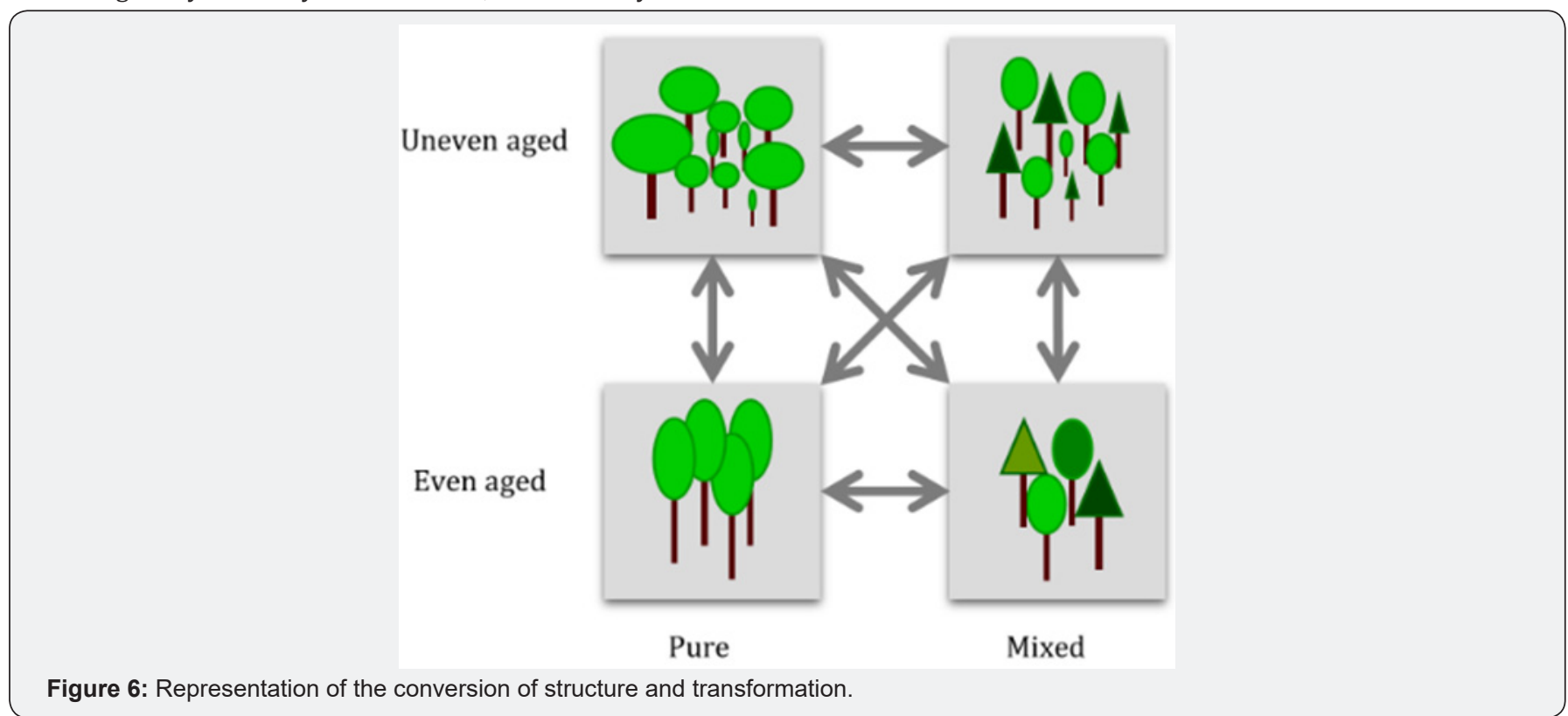

The conversion of uneven-aged in even-aged stands can be achieved by one or a set of cutting operations or natural disturbances that remove the former stand, so that the regeneration occurs mainly at a short time interval and thus originating a single cohort, attained by natural or artificial regeneration [23].
The conversion of even-aged in uneven-aged stands increases in complexity with the increase of the number of cohorts, as recruitment has to be guaranteed periodically (the shorter the higher the number of cohorts) and it is focused on natural regeneration and on auto regulation mechanisms. The conversion of an even-aged stand starts with their evaluation 
and encompasses a set of hierarchical efforts to assure: the stand stability, the life span of the trees to be maintained during the transition phase, differentiated regeneration that enables the auto regulation, and the suitability of the uneven-aged archetype $[12,29]$. The selection of the number of cohorts is of the utmost importance, and whenever stands develop two or more unbalance cohorts are a good starting point [24]. [12] Considers three different alternatives to the conversion to the Plenterwald: classical Plenter thinning, conversion in the actual generation and conversion in the next generation. The option is dependent on the level of differentiation of the stand (decreasing from the first to the last), the presence or not of regeneration and the life span of the trees. The same author considers two rules:

i. Give enough time to the process, with the following stages of: differentiation, promotion, structural development and structure achievement ii. Decide whether to start conversion in the actual generation or in the next, depending on the vigour and life span of the trees of the over storey. These tw rules can also be applied to uneven-aged stands with less cohorts than the Plenterwald. Overall there is a wide range of structures, narrower for even-aged and broader for uneven-aged stands. As a consequence, the models of silviculture should be flexible, especially during the transition phase from one structure to the other. In Figure 7 are presented generic models of silviculture for the conversion of structure. It is considered that the starting point $(\mathrm{t}=0)$ corresponds to the moment of the first evaluation of the stand. The scheme should then be adapted according to the desired conversion of structure, setting the silvicultural practices, their timing and sequence (Figure 7).

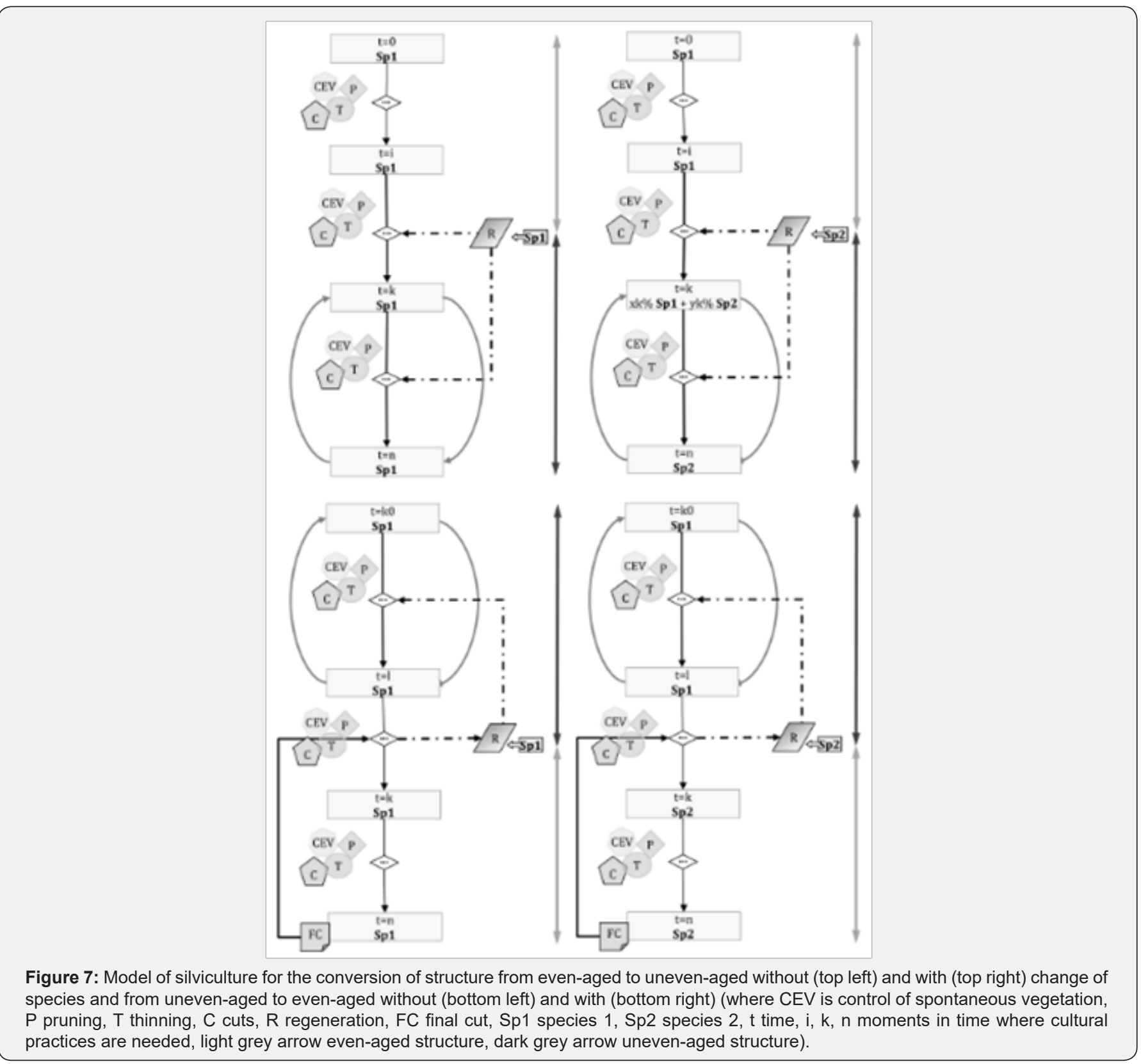




\section{Transformation}

The transformation of pure stand in mixed ones is focused in the regeneration of the species to be introduced in the stand, their proportion and spatial arrangement. Of primordial importance to the maintenance of mixed stands is also the phenomenon of compatibility, complementarity, forest tree shade tolerance, intra and inter specific competition and the growths patterns of each species [22,29]. Conversely, transformation of mixed stands in pure ones can be made selecting the desired species and promoting a set of cuts to remove more or less gradually the other species and promoting the regeneration and recruitment of the desired species. It can be carried out both on even-aged and on uneven-aged stands.

In the transformation the initial phases are critical to reach the desired form and degree of mixture and the silvicultural practices, especially the thinning, cuts and regeneration curtail stand structure significantly. In this alteration, the criteria and rules are similar to those used in the conversion of structure, though with some adaptations. Thus, according to the stage of structural differentiation of the stand the stand stability, the life span of the trees to be maintained during the transition phase, differentiated regeneration that enables the auto regulation and suitability to the form, type and degree of the desired mixture. By analogy to the conversion of structure, the rules to be followed are:

i. Give enough time to the process, with the following stages of differentiation, promotion, structural development and mixture achievement;

ii. Decide whether to start conversion in the actual generation or in the next, depending on the vigour and life span of the trees of the over storey.

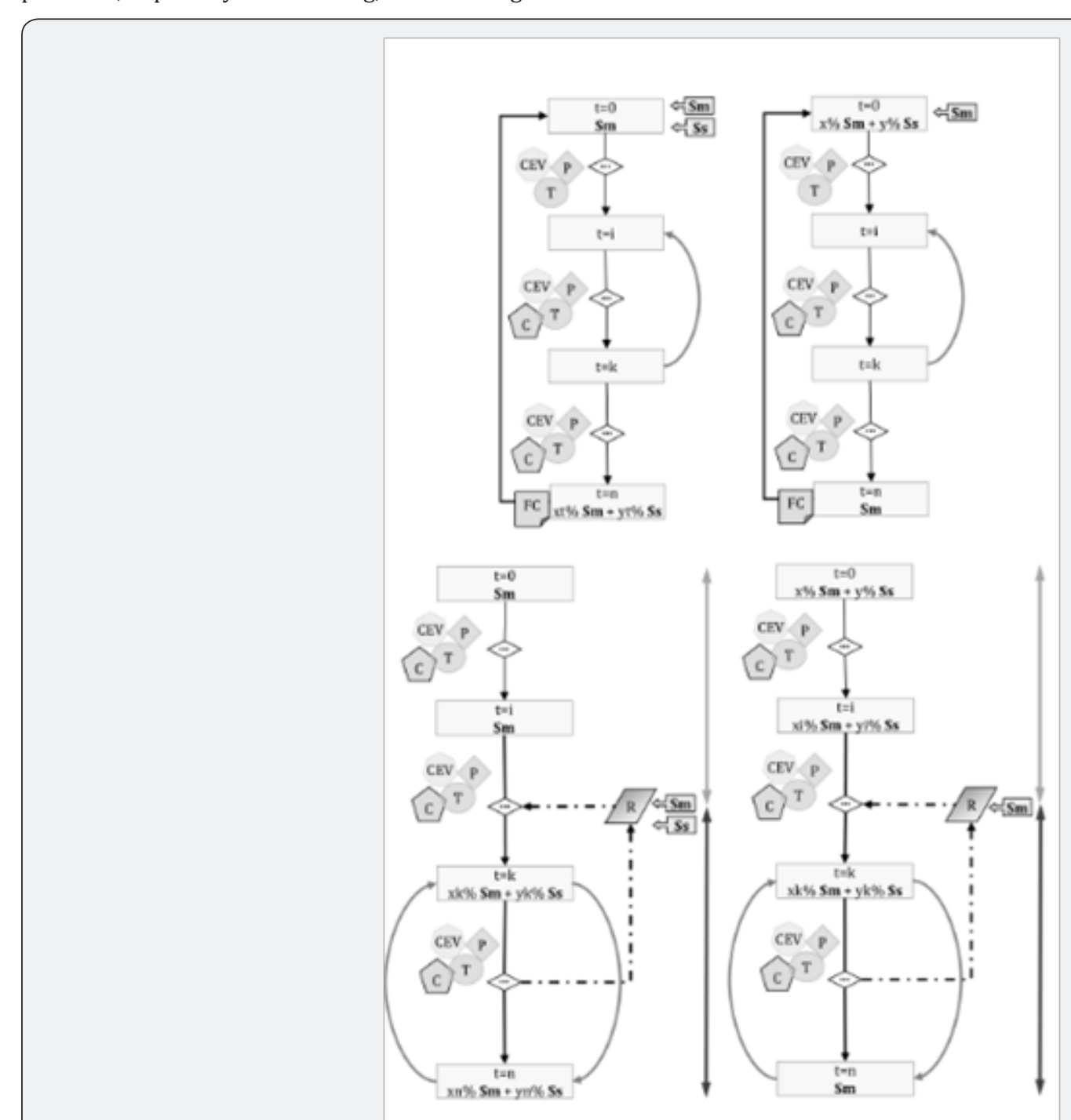

Figure 8: Model of silviculture for the transformation of a pure in mixed (top left) and mixed in pure (top right) even-aged, pure in mixed (bottom left) and mixed in pure (bottom right) uneven-aged stand (where CEV is control of spontaneous vegetation, $\mathrm{P}$ pruning, $\mathrm{T}$ thinning, $\mathrm{C}$ cuts, R regeneration, FC final cut, Sm main species, Ss secondary species, t time, i, $\mathrm{k}, \mathrm{n}$ moments in time where cultural practices are needed, light grey arrow even-aged structure, dark grey arrow uneven-aged structure). 
The transformation of pure in mixed stands comprises a set of cuts that are schedule to enable the regeneration of the desired species. The regeneration can be natural or artificial. The former is more sensitive as there have to be guaranteed seed source from the desired species which different ecological and cultural requirements. Seed trees of all the desired species have to in or in the neighbourhoods of the area to regenerate so that seed can be dispersed in all the area uniformly. Thus thinning can be prescribed to promote de seed production and cuts such as clear cuttings, shelter wood or selective cuts to remove the existing stand and promote the establishment of regeneration. In transformation with artificial regeneration after the harvest the desired species can be seeded or planted in the most suitable niches, according to their and the site characteristics. The latter can be also used to complement the natural regeneration, when it is scarce or when it is not uniformly distributed. The transformation of mixed in pure stands is implemented essentially through thinnings and cuttings, removing the individuals of all species except the desired one. The main goal is removing as early as possible the undesired species to reduce their regeneration. It can be used the natural or the artificial regeneration MacDonald et al. [102]. It can also be considered the conversion of structure and the transformation simultaneously, though it is considerable more difficult. The silvicultural operations should follow the criteria and the rules applied for both alteration processes, and seem more difficult to achieve $[103,104]$. Similarly, to the aforementioned for the structure there is a wide variability in stand composition, due to the number of species and their form type and degree. Thus, flexible models of silviculture and better suited, especially during the transformation. Figure 8 presents generic models do silviculture for the transformation. The first evaluation moment corresponds to the starting point $(\mathrm{t}=0)$ and the cultural practices schedule, type and sequence should be adapted to the stand under transformation according to the defined objectives (Figure 8).

\section{Discussion and Conclusion}

The conversion of regime results in structure and composition alterations as well as stand dynamics. The biggest alterations occur in the vertical plane with variations of the under storey density, of the height of the canopy layer and in the foliage profile [33]. Considering biodiversity and sustainability there seems to be different opinions, but, in general, it can be said that each regime has its distinctive features and a combination at landscape level of several regimes with several spatial distribution patterns will promote more diversify of the productions and services of the forest. In what regards silviculture, in the conversion of regime several methods can be used $[7,41]$.

The primordial difference between even-aged and unevenaged stands is the variety of structures, more reduced for the former and broader to the latter $[22,23,29]$. The uneven-aged structures can vary from relatively simple to very complex. The increase of complexity is linked to the number of cohorts, the proportion of individuals per cohort, density, light levels, mortality, individual tree growth and interactions between trees $[23,29]$. For the even-aged stands the development patterns are well known contrary to the uneven-aged ones. As a result, the conversion of structure can be more or less complex, short or long term lasting, and based on the diversity of management options $[12,13,22,52,53,105,106]$.

When compared with the pure stands the mixed ones provide more products and services [22,23,57], but are also more complex, especially when they are uneven-aged $[16,17,23]$. The composition complexity is related to the number of species, form, type and degree of mixture, density light levels, mortality, individual tree growth and intra and inters specific interactions. As a result, management increases in complexity from pure to mixed stand and consequently transformation can be more or less complex [12,22,103,104].

From the aforementioned it can be said that all regimes, structures and compositions contribute to the sustainability and diversity of the forest, and their products and services. The conversion of regime, structure and transformation originate more or less long transition phases and can vary from relatively simple to very complex. Considering the wide range if stand structures and site conditions it seems that the focus should be set on a suite of guidelines, flexible models of silviculture and monitoring to enable adapting the silvicultural practices, especially when the alteration of stand structure is ongoing.

\section{Acknowledgement}

The work was financed by National Funds through FCTFoundation for Science and Technology under the Project UID/ AGR/00115/2013.

\section{Conclusion}

1. The present study identifies the presence of adequate genetic variability among 6 Bulgarian peanuts varieties (Arachis hypogaea L.) of the Valencia type.

2. The information gathered from this study can be used for a future program for the selection of peanuts resistant to water stress.

3. The oldest Bulgarian variety, Sadovo 2609, has been found to use inefficient water resources in the soil.

4. It has been found that genes expressing the ratio of water to leaf area units ( $\mathrm{gH} 20 / \mathrm{cm} 2)$ are homozygous as a result of the action of inbreeding.

5. The role of environmental conditions has been established for the parameters of water exchange, chlorophyll content and leaf size in peanuts.

6. The low PCV and GCV values for most indicators show that variability is required in them.

7. The high and moderate GAM values reported in fresh and dry mass, water content, transpiration, and water-to-leaf area ratio suggest potential for genetic improvement 
8. It is recommended that future studies on water change indicators in peanuts use molecular methods to further confirm the results of this study.

\section{References}

1. Ciancio $O(2010)$ The theory of silviculture sisthemica the rationalists and the anti-rationalists, the sterile disquisitions and the sleepwalking of the forest intelligentsia. Italian Academy of Forest Sciences, Florence, Italy, p. 51.

2. Lamarque P, Quétier F, Lavorel S (2011) The diversity of the ecosystem services concept and its implications for their assessment and management. CR Biol 334(5-6): 441-449.

3. Vidal C, Lanz A, Tomppo E, Schadauer K, Gschwantner T, et al. (2008) Establishing forest inventory reference definitions for forest and growing stock: a study towards common reporting. Silva Fennica 42(2): 247-266.

4. Martine S, Castellani V, Sala S (2015) Carrying capacity assessment of forest resources: Enhancing environmental sustainability in energy production at local scale. Resour Conserv Recycl 94: 11-20.

5. Assmann E (1970) The principles of forest yield study. Pergamon Press, Oxford, UK, pp. 506.

6. Lanier L, Badré M, Delabraze P, Dubourdieu J, Flammarion JP (1986) Précis de sylviculture [Compendium of silviculture]. ENGREF, Nancy, France, pp. 468.

7. Boudru M (1989) Forest and silviculture. The treatment of forests Tome 2. Presses Agronomiques de Gembloux, Gembloux, France, pp 344

8. Matthews JD (1989) Silvicultural systems. Claredon Press, Oxford, UK, pp. 284.

9. Schütz JP (1990) Silviculture 1. Principals of tending forests. Presses Polytechniques et Universitaires Romandes, Lausanne, Switzerland, pp. 245 .

10. Perkey AW, Wilkins BL, Smith HC (1993) Crop tree management in Eastern hardwoods. NA-TP-19-93. USDA: Forest Service, Morgantown, USA, p. 57.

11. Schütz JP (1999) Close-to-nature silviculture: is this concept compatible with species diversity? Forestry 72(4): 359-366.

12. Schütz JP (2001) Opportunities and strategies of transforming regular forests to irregular forests. Forest Ecol Manag 151(1-3): 87-94.

13. Schütz JP (2002) Silvicultural tools to develop irregular and diverse forest structures. Forestry 75(4): 329-337.

14. Diaci J, Kerr G, O'Hara K (2011) Twenty-first century forestry: integrating ecologically based, uneven-aged silviculture with increased demands on forests. Forestry 84(5): 463-465.

15. Mc Evoy TJ (2003) Positive impact forestry. A sustainable approach to managing woodlands. Island PRESS, Washington, USA, pp. 288.

16. Pommerening A, Murphy ST (2004) A review of the history, definitions and methods of continuous cover forestry with special attention to afforestation and restocking. Forestry 77(1): 27-44.

17. Puettmann KJ, Coates KD, Messier C (2009) A Critique of Silviculture. Island Press, Washington, USA, pp. 188.

18. Ciancio O, Nocentini S (2011) Biodiversity conservation and systemic silviculture: concepts and applications. Plant biosystems 145(2): 411. 418

19. Moravčík M, Sarvašová Z, Merganič J, Kovalčík M (2012) Close to Nature Management in High-Mountain Forests of Norway Spruce Vegetation Zone in Slovakia. In: Blanco JA \& Lo YH (Eds.), Forest Ecosystems-More than Just Trees. In Tech, Rijeka, Croatia, pp. 375-414.
20. Schütz JP, Pukkala T, Donoso P J, Gadow Kv (2012) Historical Emergence and Current Application of CCF. In: Pukkala T \& Gadow Kv (Eds.), Continuous Cover Forestry, Springer Science C Business Media BV, Dordrecht, The Netherlands, p. 1-28.

21. Bauhus J, Puettmann KJ, Kühne C (2013) Is close-to-nature forest management in Europe compatible with managing forests as complex adaptive forest ecosystems? In: Messier C, et al. (Eds.), Managing Forests as Complex Adaptive Systems: building resilience to the challenge of global change. Routledge, New York, USA, pp. 187-213.

22. O'Hara KL (2014) Multiaged silviculture: Managing for complex forest stand structures. Oxford University Press, Oxford, UK, pp. 213.

23. Oliver CD, Larson BC (1996) Forest stand dynamics. John Wiley \& sons, Inc., New York, USA, pp. 544.

24. Smith DM, Larson BC, Kelty M J, Ashton PMS (1997) The practice of silviculture. Applied forest ecology. ( $9^{\text {th }}$ edn), John Wiley \& Sons, Inc., New York, USA, pp. 560.

25. O'Hara KL, Milner KS (1994) Describing forest and structure: some old and new approaches. In: Costa MEP \& Preuhsler T (Eds.), Proceedings Growth models for tree and stand simulation, Portugal, p. 43-56.

26. Mason WL (2002) Are irregular stands more windfirm? Forestry 75(4): 347-355.

27. Gardiner B, Marshall B, Achim A, Belcher RE, Wood CJ (2005) The stability of different silvicultural systems: a wind-tunnel investigation. Forestry 78(5): 471-484.

28. Gardiner B, Byrne K, Hale S, Kamimura K, Mitchell SJ, et al. (2008) A review of mechanistic modelling of wind damage risk to forests. Forestry 81(3): 447-463.

29. Schütz JP (1997) Silviculture 2. The management of even-aged and mixed forests. Presses Polytechniques et Universitaires Romandes, Lausanne, Switzerland, pp. 178.

30. Gadow Kv, Zhang CY, Wehenkel C, Pommerening A, Corral-Rivas J, et al. (2012) Forest Structure and Diversity. In: Pukkala T \& von Gadow K (Eds.), Continuous Cover Forestry. Springer Science + Business Media, Dordrecht, The Netherlands, p. 29-83.

31. Florence RG (1996) Ecology and silviculture of eucalyptus forests. CSIRO, Collingwood, Australia, pp. 415.

32. Szabó P, Müllerová J, Suchánková S, Kotačka M (2015) Intensive woodland management in the middle ages: Spatial modelling based on archival data. Journal of Historical Geography 48: 1-10.

33. Kirby KJ, Buckley GP, Mills J (2017) Biodiversity implications of coppice decline, transformations to high forest and coppice restoration in British woodland. Folia Geobot 52(1):5-13.

34. Müllerová J, Szabó P, Hédl R (2014) The rise and fall of traditional forest management in southern Moravia: a history of the past 700 years. For Ecol Manage 331: 104-115.

35. Mattioli W, Ferrari B, Giuliarelli D, Mancini L, Portoghesi L, et al. (2015) Conversion of mountain beech coppices into high forest: an example for ecological intensification. Environ Manag 56(5): 1159-69.

36. Stojanović M, Sánchez-Salguero S, Levanič T, Szatniewska J, Pokorný $\mathrm{R}$, et al. (2017) Forecasting tree growth in coppiced and high forests in the Czech Republic. The legacy of management drives the coming Quercus petraea climate responses. Forest Ecol Manag 405: 56-68.

37. Suchomel C, Pyttel P, Becker G, Bauhus J (2012) Biomass equations for sessile oak (Quercus petraea (Matt.) Liebl.) and hornbeam (Carpinus betulus $L$.) in aged coppiced forests in southwest Germany. Biomass Bioenergy 46: 722-730.

38. Bruckman VJ, Terada T, Fukuda K, Yamamoto H, Hochbichler E (2016) Overmature periurban Quercus-Carpinus coppice forests in Austria and Japan: a comparison of carbon stocks, stand characteristics and conversion to high forest. Eur J For Res 135(5): 857-869. 
39. Kopecký M, Hédl R, Szabó P (2013) Non-random extinctions dominate plant community changes in abandoned coppices. J Appl Ecol 50(1): 79-87.

40. Pérez S, Renedo CJ, Ortiz A, Mañana M, Delgado F (2011) Energetic density of different forest species of energy crops in Cantabria (Spain). Biomass Bioenergy 35(11): 4657-4664.

41. Ciancio O, Corona P, Lamonaca, A, Portoghesi L, Travaglini D (2006) Conversion of clearcut beech coppices into high forests with continuous cover: A case of study in central Italy. Forest Ecol Manag 224(3): 235240

42. Pietras J, Stojanović M, Knott R, Pokorný R (2016) Oak sprouts grow better than seedlings under drought stress. iForest-Biogeosci For 9(4):529-535.

43. Salomón R, Rodríguez-Calcerrada J, Zafra E, Morales-Molino C Rodríguez-García A, et al. (2016) Unearthing the roots of degradation of Quercus pyrenaica coppices: a root-to-shoot imbalance caused by historical management? For Ecol Manage 363: 200-211.

44. Stojanović M, Čater M, Pokorný R (2016) Responses in young Quercus petraea: coppices and standards under favourable and drought conditions. Dendrobiology 76: 127-136.

45. Cook J, Beyea J (2000) Bioenergy in the United States: progress and possibilities. Biomass Bioenergy 18(6): 441-455.

46. Swank WT, Vose JM, Elliott KJ (2001) Long-term hydrologic and water quality responses following commercial clearcutting of mixed hardwoods on a southern Appalachian catchment. For Ecol Manag 143(1-3): 163-178.

47. Berndes G, Hoogwijk M, van den Broek R (2003) The contribution of biomass in the future global energy supply: a review of 17 studies. Biomass Bioenergy 25(1):1-28

48. Belleau A, Brais S, Paré D (2006) Soil Nutrient Dynamics after Harvesting and Slash Treatments in Boreal Aspen Stands. Soil Sci Soc Am J 70(4): 1189-1199.

49. Shepard JP (2006) Water quality protection in bioenergy production: the US system of forestry Best Management Practices. Biomass Bioenergy 30(4): 378-384

50. Van Calster H, Baeten L, De Schrijver A, De Keersmaeker L, Rogister JE, et al. (2007) Management driven changes (1967-2005) in soil acidity and the understorey plant community following conversion of a coppice-with-standards forest. For Ecol Manag 241(1-3): 258-271.

51. O'Hara K (2001) The silviculture of transformation-a commentary. Forest Ecol Manag 151: 81-86.

52. O’Hara KL, Gersonde RF (2004) Stocking control concepts in unevenaged silviculture. Forestry 77(2): 131-143.

53. O'Hara KL, Nagel LM (2006) A functional comparison of productivity in even-aged and multiaged stands: a synthesis for Pinus ponderosa. For Sci 52(3): 290-303.

54. Rackham 0 (1992) Mixtures, mosaics and clones: the distribution of trees within European woods and forests. In: Cannell MGR, et al. (Eds.), The ecology of mixed species stands of trees, Editora, city, country, $\mathrm{p}$. 1-20.

55. Köhl M, Päivinen R, Traub B, Miina S (1997) Comparative Study. In: Study on European Forestry information and communication system. European Commission. Reports on forest inventory and survey systems 2: $1265-1322$

56. Gardiner JJ (1999) Changing forests, management and growing conditions. In: Olsthoorn AFM, et al. (Eds.), Management of mixedspecies forest: silviculture and economics. DLO Institute for Forestry and Nature Research, Wageningen, The Netherlands, p. 17-19.
57. Bravo-Oviedo A, Pretzsch H, Ammer C, Andenmatten E, Antón C, et al. (2014) European mixed forests: definition and perspectives. Forest systems 23(3): 518-533.

58. Gonçalves AC (2017) Multi-species stand classification: definition and perspectives. In: Chakravarty S \& Shukla G (Eds.), Forest Ecology and Conservation, InTech, Rijeka, Croatia, p. 4-23.

59. Leikola M (1999) Definition and classification of mixed forests, with special emphasis on boreal forests. In: Olsthoorn AFM, et al. (Eds.), In: Management of mixed-species forest: silviculture and economics, DLO Institute for Forestry and Nature Research, Wageningen, The Netherlands, p. 20-28.

60. Bartelink JJ, Olsthoorn M (1999) Introduction: mixed forest in western Europe. In: Olsthoorn AFM, et al. (Eds.), Management of mixed-species forest: silviculture and economics. DLO Institute for Forestry and Nature Research, Wageningen, The Netherlands, p. 9-16.

61. Spies T (1997) Forest Stand Structure, Composition, and Function. In: Kohm KA \& Franklin JF (Eds.), Creating a forestry for the $21^{\text {st }}$ Century. Island Press, Washington, USA, p. 11-30.

62. Brockway DG (1998) Forest plant diversity at local and landscape scales in the Cascade Mountains of southwestern Washington. Forest Ecol Manag 109: 323-341.

63. Lawesson JE, Blust Gde, Grashof C, Firbank L, Honnay O, et al. (1998) Species diversity and area-relationship in Danish beech forests. Forest Ecol Manag 106(2-3): 235-245.

64. Pitkänen S (1998) The use of diversity indices to assess the diversity of vegetation in managed boreal forests. Forest Ecol Manag 112(1-2): 121-137.

65. Gaines WL, Harrod RJ, Lehmkuhl JF (1999) Monitoring biodiversity: quantification and interpretation. PNW-GTR-443. USDA: Forest Service, p. 27.

66. Neumann M, Starlinger F (2001) The significance of different indices for stand structure and diversity in forests. Forest Ecol Manag 145(12): 91-106.

67. Staudhammer CL, Lamey VM (2001) Introduction and evaluation of possible indices of stand and structural diversity. Can J For Res 31(7): 1105-1115.

68. Gilliam FS (2002) Effects of harvesting on herbaceous layer diversity of a central Appalachian hardwood forest in West Virginia, USA. Forest Ecol Manag 155(1-3): 33-43.

69. Knoke T, Stimm B, Ammer C, Moog M (2005) Mixed forests reconsidered: A forest economics contribution on an ecological concept. Forest Ecol Manag 213(1-2): 102-116.

70. Forrester DI, Kohnle U, Albrecht AT, Bauhus J (2013) Complementarity in mixed-species stands of Abies alba and Picea abies varies with climate, site quality and stand density. Forest Ecol Manag 304: 233242.

71. Forrester DI (2014) The spatial and temporal dynamics of species interactions in mixed-species forests: from pattern to process. Forest Ecol Manag 312: 282-292.

72. Ducey MJ, Knapp R (2010) A stand density index for complex mixed species forests in the northeastern United States. Forest Ecol Manag 260(9): 1613-1622.

73. Dirnberger GF, Sterba H (2014) A comparison of different methods to estimate species proportions by area in mixed stands. Forest Systems 23(3): 534-546.

74. Sterba H, Río Md, Brunner A, Condes S (2014) Effect of species proportion definition on the evaluation of growth in pure vs. mixed stands. Forest Systems 23(3): 547-559. 
75. Forrester DI, Bauhus J, Cowie AL (2006) Carbon allocation in a mixedspecies plantation of Eucalyptus globulus and Acacia mearnsii. For Ecol Manag 233(2-3): 275-284.

76. Pretzsch H, Schütze G (2009) Transgressive overyielding in mixed compared with pure stands of Norway spruce and European beech in Central Europe: evidence on stand level and explanation on individual tree level. Eur J For Res 128(2): 183-204.

77. Pretzsch H, Block J, Dieler J, Dong PH, Kohnle U, et al. (2010) Comparison between the productivity of pure and mixed stands of Norway spruce and European beech along an ecological gradient. Ann For Sci 67(7):712-712.

78. del Río M, Sterba H (2009) Comparing volume growth in pure and mixed stands of Pinus sylvestris and Quercus pyrenaica. Ann For Sci 66(5): 502-502.

79. Bayer D, Seifert S, Pretzsch H (2013) Structural crown properties of Norway spruce [Picea abies (L.) Karst.] and European beech [Fagus sylvatica (L.)] in mixed versus pure stands revealed by terrestrial laser scanning. Trees 27(4): 1035-1047.

80. Dieler J, Pretzsch H (2013) Morphological plasticity of European beech (Fagus sylvatica L.) in pure and mixedspecies stands. Forest Ecol Manag 295:97-108.

81. Metz J, Seidel D, Schall P, Scheffer D, Schulze E, et al. (2013) Crown modeling by terrestrial laser scanning as an approach to assess the effect of aboveground intra- and interspecific competition on tree growth. Forest Ecol Manag 310: 275-288.

82. Philip MS (1994) Measuring trees and forests. ( $2^{\text {nd }}$ edn), CAB International, Cambridge, UK, pp. 310.

83. Hasenauer H (1997) Dimensional relationships of open-grown trees in Austria. For Ecol Manage 96(3): 197-206.

84. Peltola H, Nykänen M-L, Kellomäki S (1997) Model computations on the critical combination of snow loading and windspeed for snow damage of Scots pine, Norway spruce and Birch sp. at stand edge. Forest Ecol Manag 95(3): 229-241.

85. Wonn WT, O’Hara KL (2001) Height:Diameter Ratios and Stability Relationships for Four Northern Rocky Mountain Tree Species. WJAF 16(2): 87-94.

86. Laar Av, Akça A (2009) Forest msensuration. Sringer. Sringer, Dordrecht, The Netherlands, pp. 383.

87. Vospernik S, Monserud RA, Sterba H (2010) Do individual-tree growth models correctly represent height:diameter ratios of Norway spruce and Scots pine? Forest Ecol Manag 260(10): 17351753.

88. Pretzsch H (1998) Structural diversity as a result of silvicultural operations. Lesnictví-Forestry 44: 429-439.

89. Schulte BJ, Buongiorno J (1998) Effects of uneven-aged silviculture on the stand structure, species composition, and economic returns of loblolly pine stands. Forest Ecol Manag 111(1): 83-101.

90. Gadow Kv, Hui G (2002) Characterising forest spatial structure and diversity. In: Bjoerk L (Ed), Proceedings IUFRO Int. workshop 'Sustainable forestry in temperate regions', Sweden, pp. 20-30.
91. Pommerening A (2002) Approaches to quantifying forest structures. Forestry 75(3): 305-324.

92. Sterba H, Ledermann T (2006) Inventory and modelling for forests in transition from even-aged to uneven-aged management. Forest Ecol Manag 224(3): 278-285.

93. Aguirre O, Hui GY, Gadow Kv, Jiménez J (2003) An analysis of spatial forest structure using neighbourhood-based variables. Forest Ecol Manag 183(1-3): 137-145.

94. McElhinny C, Gibbons P, Brack C, Bauhus J (2005) Forest and woodland stand structural complexity: Its definition and measurement. Forest Ecol Manag 218(1-3): 1-24.

95. Lexerod NL, Eid T (2006) An evaluation of different diameter indices based on criteria related to forest management planning. Forest Ecol Manag 222(1-3): 17-28.

96. Pommerening A (2006) Transformation to continuous cover forestry in a changing environment. Forest Ecol Manag 224: 227-228.

97. Gonçalves AC, Oliveira AC, Dias SS (2010) Evolution in multi-species high forest stands in Serra da Lousã: Diversity analysis. Silva Lusitana, no especial: 79-90.

98. Gonçalves AC, Oliveira AC (2011) Regeneration in multi-species in Serra da Lousã. Forest Systems 20(3): 444-452.

99. Serrada R, Bravo A, Sánchez I, Allué M, Elena R, et al. (1998) Conversion into high forest in coppices of Quercus ilex subs. ballota L. In Central region of Iberian Peninsula. Annali dell Istituto Sperimentale per la Selvicoltura 27:149-160.

100.Cutini A, Chianucci F, Giannini T, Manetti MC, Salvati L (2015) Is anticipated seed cutting an effective option to accelerate transition to high forest in European beech (Fagus sylvatica L.) coppice stands? Ann For Sci 72(5): 631-640.

101.Vrška T, Janík D, Pálková M, Adam D, Trochta J (2016) Below and above-ground biomass, structure and patterns in ancient lowland coppices. iForest-Biogeosciences 10: 23-31.

102.Davies 0, Haufe J, Pommerening A (2008) Silvicultural principles of continuous cover forestry. A guide to best practice. . Forestry Commission Wales, England, UK, pp. 111.

103.Cameron AD, Hands MOR (2010) Developing a sustainable irregular structure: an evaluation of three inventories at 6-year intervals in an irregular mixed-species stand in Scotland. Forestry 83(5): 469475.

104.Kerr G, Morgan G, Blyth J, Stokes V (2010) Transformation from evenaged plantations to an irregular forest: the world's longest running trial area at Glentress, Scotland. Forestry 83(3): 329-344.

105.0'Hara KL, Ramage BS (2013) Silviculture in an uncertain world: utilizing multi-aged management systems to integrate disturbance. Forestry 86(4): 401-410.

106.Serrada R, San Miguel A (1998) The coppice system in Spain. Current situation, state of art and major areas to be investigated. Annali dell Istituto Sperimentale per la Selvicoltura 27: 266275. 
This work is licensed under Creative

Commons Attribution 4.0 License

DOI: 10.19080/JOJHA.2018.01.555564

\section{Your next submission with Juniper Publishers} will reach you the below assets

- Quality Editorial service

- Swift Peer Review

- Reprints availability

- E-prints Service

- Manuscript Podcast for convenient understanding

- Global attainment for your research

- Manuscript accessibility in different formats ( Pdf, E-pub, Full Text, Audio)

- Unceasing customer service

Track the below URL for one-step submission https://juniperpublishers.com/online-submission.php 